Magdalena Walicka1 ${ }^{1}$ Marcin Chlebus ${ }^{2}$, Melania Brzozowska³, Andrzej Śliwczyński ${ }^{3}$ 4, Tadeusz Jędrzejczyk³ , Lidia Kania ${ }^{1,5}$, Monika Puzianowska-Kuźnicka 5, 6, Edward Franek ${ }^{1,5}$

${ }^{1}$ Department of Internal Diseases, Endocrynology and Diabetology of the Central Clinical Hospital of the Ministry of the Interior in Warsaw

${ }^{2}$ Department of Quantitative Finance, Faculty of Economic Sciences, Warsaw University

${ }^{3}$ National Health Fund

${ }^{4}$ Public Health Department, Faculty of Health Science of the Medical University in Łódź

${ }^{5} \mathrm{Clinical-Research} \mathrm{Complex} \mathrm{of} \mathrm{Human} \mathrm{Epigenetics} \mathrm{Institute} \mathrm{of} \mathrm{Experimental} \mathrm{and} \mathrm{Clinical} \mathrm{Medicine} \mathrm{named} \mathrm{after} \mathrm{M.} \mathrm{Mossakowski} \mathrm{PAN} \mathrm{in} \mathrm{Warsaw}$

${ }^{6}$ Institute of Gerontology and Geriatrics Postgraduate Education Medical Center Warsaw

\title{
Prevalence of diabetes in Poland in the years 2010-2014
}

\section{ABSTRACT}

Introduction. Each year diabetes affects larger and larger number of people. Despite this fact, the number of people suffering from diabetes in Poland is not known precisely. In order to assess this prevalence, the thesis aims at assessing the prevalence of diabetes in the years 2010-2014 in the total Polish population by using the databases of the National Health Fund. Material and methods. In the period from $1^{\text {st }}$ January 2010 until 31 $1^{\text {st }}$ December 2014 patients were distinguished according to PESEL (Personal Identification) numbers: 1. for whom health care providers have indicated diabetes-related ICD-10 codes as the main cause of the medical intervention in billing reports; 2 . who had got their prescriptions filled for any hypoglycemic agents or for glucose meter test strips. The number of patients recorded as diabetes patients according to the ICD-10 code and the number of patients who had their prescriptions filled for hypoglycemic agents or test strips were assessed. On the basis of these data the prevalence of diabetes (percentage of people with diabetes in a given year or a percentage of people who had got their prescriptions filled for hypoglycemic

Address for correspondence:

prof. dr hab. n. med. Edward Franek

Klinika Chorób Wewnętrznych, Endokrynologii i Diabetologii

CSK MSW

ul. Wołoska 137, 02-507 Warszawa

e-mail: edward.franek@cskmswia.pl

Clinical Diabetology 2015, 4, 6, 232-237

DOI: 10.5603/DK.2015.0031

Translation: GROY Translations

Received: 05.12.2015

Accepted: 09.12.2015 agents or test strips in relation to the general population) in respective years and an average prevalence rate for respective voivodeships were assessed.

Results. The average percentage of people with diabetes in the years 2010-2014 were found to be $4.47 \%$ ( $\pm 0.09 \%$ ). This percentage has gradually increased in the consecutive years from $4.39 \%$ in 2010 to $4.61 \%$ in 2014. The average percentage of people who had got their prescriptions filled for diabetes related medicines or glucose meter test strips amounted to $5.88 \%$ in the years 2010-2014. The largest percentage of people with diabetes was in Silesian Voivodeship and amounted to $5.5 \%$ ( $\pm 0.1 \%$ ), the second consecutive voivodeship was Łódź with $5.0 \%( \pm 0.2 \%)$ of people with diabetes and Opole Voivodeship on the third place with $4.9 \%(0.1 \%)$ inhabitants with diabetes. The smallest percentage of people with diabetes was noted in Warmian-Masurian Voivodeship - 3.5\% ( $\pm 0.1 \%)$ and Subcarpathian Voivodeship $-3.6 \%$ ( $\pm 0.2 \%$ ).

Conclusions. 1. Average diabetes prevalence rate in Poland in the years 2010-2014 amounted to $4.47 \%$ (the assessment was carried out on the basis of the number of people recorded by the National Health Fund as patients with diabetes) or $5.88 \%$ (assessment on the basis of the number of people who got their prescriptions filled for reimbursable hypoglycemic agents or glucose meter test strips). 2. Diabetes prevalence in Poland increases in the consecutive years. 3. Prevalence of diabetes varies among voivodeships. (Clin Diabet 2015; 4, 6: 232-237)

Key words: diabetes, prevalence, Poland, National Health Fund 


\section{Introduction}

Due to an unhealthy lifestyle, too little physical activity and the increase of cases of overweight and obesity, prevalence of diabetes increases at an alarming rate in all regions of the world [1,2]. According to the IDF (International Diabetes Federation) data, there were 387 million people with diabetes in the world in 2014 and this disease has not been diagnosed among more than $46 \%$ of these people [3]. The World Health Organization (WHO) points to diabetes as one of the most serious threats of this century. It is the first and so far the only non-infectious disease which has been recognized by the United Nations as the epidemic of the $21^{\text {st }}$ century [4].

The mortality of people with diabetes is higher and their expected survival is shorter in comparison with people not affected by diabetes [5]. WHO predicts that in 2030 diabetes will be the seventh leading cause of death worldwide [6].

Diabetes also involves considerable financial burdens on the state budget. In 2013 about 2.5 billion PLN was spent in Poland for the treatment of this disease (in comparison with 2012, the expenditures increased by $3.6 \%$ ) [7].

Due to the exponential increase of people with diabetes, it is necessary to provide a high quality of a well organized diabetes care. In order to plan these actions it is necessary to possess knowledge about the scale of the problem in our country. Unfortunately, the number of people with diabetes in Poland is not precisely known because we do not have a national register of people suffering from this disease. The available data concerning diabetes epidemiology in Poland derive from research which was carried out by means of different selection criteria on groups of patients in different age brackets with different types of diabetes, in separate cities or regions [9-17]. Studies were also carried out on representative samples of the Polish population, however, they also have their limits. For example, no blood glucose concentration curves were carried out in any of these studies, in NATPOL studies the population from the age of 18 was assessed and in the POLSENIOR and WOBASZ studies the population was limited to older people [18-21]. That is why this thesis aims at assessing the prevalence of diabetes in the years 2010-2014 in the total Polish population by using the data of the National Health Fund (NFZ).

\section{Material and methods}

The Polish system of healthcare is based on the insurance model. The public authorities ensure that all Polish citizens have equal access to healthcare services financed by public funds. The National Health Fund
[22] is the health insurance institution performing the function of the payer. The National Health Fund finances health services which are granted to the insured people and reimburses medicines, foodstuffs and medical devices from resources from compulsory health insurance premiums.

Healthcare services are provided by the healthcare providers who concluded contracts about providing healthcare services with the National Health Fund. The healthcare providers providing (outpatient, as well as, hospital) healthcare services create and keep a register of healthcare services in an electronic form which records all data characterizing each granted service. The data concerning the granted health service cover, among others, information characterizing the person who was provided with medical services (ie., PESEL Personal Identification No.) and the disease entity code according to the ICD-10 classification, being the main reason for the provided service. These data are passed on to the National Health Fund [23].

The pharmacies are also obliged to collect and transfer data resulting from the filled prescriptions to the National Health Fund. The scope of the collected and transferred information containing data about the trade imedicines, foodstuffs for particular nutritional uses, medical devices subject to reimbursement, determined for each issued package or part of the package includes, among others, the PESEL of the patient who received the prescription and the code number of the medicine, foodstuff for particular nutritional uses or medical device (EAN, European Article Number) [24].

$A$ retrospective analysis of the data base of the National Health Fund was carried out in the study. In the period from $1^{\text {st }}$ January 2010 until $31^{\text {st }}$ December 2014 patients were distinguished according to the PESEL (personal identification) numbers:

- for whom healthcare providers have disclosed the ICD-10 codes related to diabetes as the main cause of the medical intervention in the billing reports from services: E10 - insulin-dependent diabetes mellitus, E11 - noninsulin dependent diabetes mellitus, E12 - malnutrition-related diabetes, E13 - other undefined forms of diabetes, E14 undefined diabetes;

- who had got their prescriptions filled for any reimbursable hypoglycemic agent (insulins, oral antidiabetics) and/or for reimbursable glucose meter test strips.

The number of patients registered as diabetic patients and the number of patients who got their prescriptions filled for hypoglycemic agents or test strips were assessed each year. The diabetes prevalence rate was calculated on the basis of the Polish demographic 
data worked out by the Main Statistical Office [25]. The prevalence rate was defined as the percentage of people recorded as patients with diabetes or a percentage of people who got their prescriptions filled for hypoglycemic agents or test strips in a given year in relation to the general population. The average percentage of people recorded as people with diabetes was also assessed in the analyzed period and the prevalence rate per 100 thousand people was calculated in respective voivodeships.

\section{Statistical methods}

The analysis in the research was carried out on the basis of descriptive statistics: average values and standard deviations. Additionally, in order to compare the percentage of people recorded as patients with diabetes and those who bought pharmaceuticals associated with diabetes or blood glucose meter test strips in relation to the general population in the consecutive years, $\chi^{2}$ Pearson tests, Fisher's exact probability test and the proportion test were carried out. All tests were verified on three materiality levels $(5 \%, 1 \%$ and $0.1 \%)$.

\section{Results}

Table 1 presents the number and percentage of patients recorded as subjects with diabetes according to the adequate ICD-10 codes and the number and percentage of patients who had the prescriptions filled for reimbursable hypoglycemic agents or reimbursable blood glucose meter test strips in the consecutive years. The average percentage of people recorded as patients with diabetes according to the ICD-10 codes in the years 2010-2014 amounted to $4.47 \%( \pm 0.09 \%)$. The lower chart in figure 1 shows that this percentage has successively increased in the consecutive years and each increase is statistically significant (the significance of the difference calculated for the percentages of two successive years). However, the average percentage of people who bought medicines related to diabetes or test strips in the years 2010-2014 amounted to $5.88 \%$ ( $\pm 0.32 \%$ ). In this case it can be noted that this percentage increased in 2011 and then significantly decreased in 2012. Significant increases were recorded again in the years 2013 and 2014 (Figure 1, upper line).

Table 2 presents the average percentage of people recorded as patients with diabetes (according to the ad-

Table 1. Number of patients with diagnosed diabetes (according to reported ICD-10 codes) and subjects who filled prescriptions for anti-diabetic drugs and/or glucose meter strips in the years 2010-2014

\begin{tabular}{lcc}
\hline Year & Number of patients with diagnosed diabetes & Number of patients who filled the prescriptions \\
\hline $2010, \mathrm{n}(\%)$ & $1678187(4.39 \%)$ & $2215080(5.80 \%)$ \\
$2011, \mathrm{n}(\%)$ & $1697277\left(4.40 \%^{*}\right)$ & $2433433\left(6.31 \%^{* * *}\right)$ \\
$2012, \mathrm{n}(\%)$ & $1702129\left(4.4 \%^{* *}\right)$ & $2109263\left(5.47^{* * *}\right)$ \\
$2013, \mathrm{n}(\%)$ & $1731341\left(4.50 \%^{* * *}\right)$ & $2213815\left(5.75 \%^{* * *}\right)$ \\
$2014, \mathrm{n}(\%)$ & $1775745\left(4.61 \%^{* * *}\right)$ & $2339889\left(6.08 \%^{* * *}\right)$ \\
\hline
\end{tabular}

${ }^{*} p<0.05 ; * * p 0.01 ; * * * p<0.001$

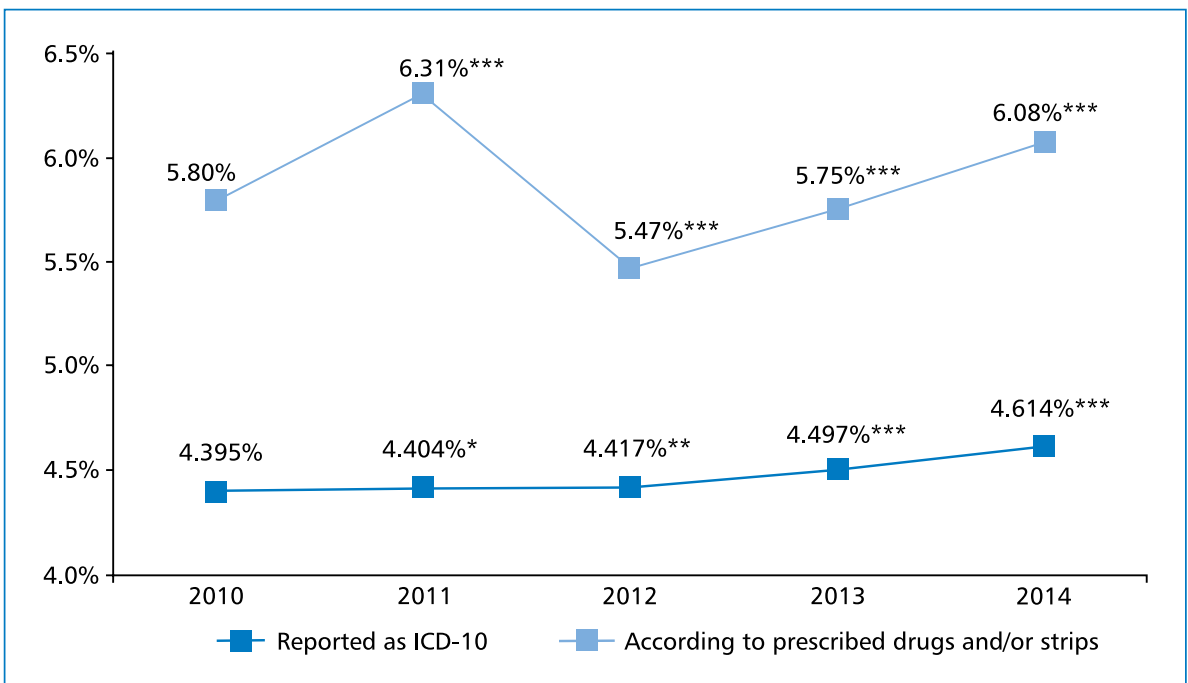

Figure 1. Percentage number of subjects with diagnosed diabetes (according to reported ICD-10 codes) and subjects who filled prescriptions for antidiabetic drugs and/or glucose meter strips in the years 2010-2014 
Table 2. Mean (from the years 2010-2014), percentage of subjects with diagnosed diabetes (according to reported ICD-10 codes) and prevalence index (per 100.000 inhabitants) in the particular regions (voivodeships)

\begin{tabular}{lcc}
\hline Region (voivodeship) & $\begin{array}{c}\text { Percentage of people recorded } \\
\text { as diabetes patients }\end{array}$ & $\begin{array}{c}\text { Prevalence rate per 100 } \\
\text { thousand population }\end{array}$ \\
\hline Lower silesia & $4.7 \%( \pm 0.1 \%)$ & $4697( \pm 121.8)$ \\
Kuyavian-Pomeranian & $4.6 \%( \pm 0.1 \%)$ & $4574( \pm 47.7)$ \\
Lublin & $4.3 \%( \pm 0.1 \%)$ & $4323( \pm 67.6)$ \\
Lubusz & $4.5 \%( \pm 0.1 \%)$ & $4483( \pm 103.2)$ \\
Łódź & $5.0 \%( \pm 0.2 \%)$ & $5028( \pm 167.3)$ \\
Lesser Poland & $4.0 \%( \pm 0.1 \%)$ & $4014( \pm 147.8)$ \\
Masovian & $4.3 \%( \pm 0.1 \%)$ & $4274( \pm 95.3)$ \\
Opole & $4.9 \%( \pm 0.1 \%)$ & $4916( \pm 72.0)$ \\
Subcarpathian & $3.6 \%( \pm 0.2 \%)$ & $3625( \pm 154.9)$ \\
Podlaskie & $3.9 \%( \pm 0.1 \%)$ & $3870( \pm 112.3)$ \\
Pomeranian & $4.6 \%( \pm 0.1 \%)$ & $4595( \pm 57.3)$ \\
Silesian & $5.5 \%( \pm 0.1 \%)$ & $5458( \pm 78.8)$ \\
Świętokrzyskie & $4.6 \%( \pm 0.1 \%)$ & $4605( \pm 51.8)$ \\
Warmian-Masurian & $3.5 \%( \pm 0.1 \%)$ & $3459( \pm 110.4)$ \\
Greater Poland & $4.5 \%( \pm 0.2 \%)$ & $4479( \pm 184.6)$ \\
West Pomeranian & $4.5 \%( \pm 0.1 \%)$ & $4515( \pm 83.0)$ \\
Poland & $4.5 \%( \pm 0.1 \%)$ & $4497( \pm 94.7)$ \\
\hline
\end{tabular}

equate ICD-10 codes) and the average prevalence rate per 100 thousand residents in the analyzed period in respective voivodeships. The largest percentage of people registered as patients with diabetes was recorded in Silesian Voivodeship and amounted to $5.5 \%$ ( $\pm 0.1 \%)$, the next consecutive voivodeship was Łódź Voivodeship $-5.0 \%( \pm 0,2 \%)$ and the third one was Opole Voivodeship $-4.9 \%(0.1 \%)$. The smallest percentage of people registered as patients with diabetes was recorded in Warmian-Masurian Voivodeship $-3.5 \%( \pm 0.1 \%)$ and Subcarpathian Voivodeship $-3.6 \%$ ( $\pm 0.2 \%)$.

\section{Discussion}

The average percentage of people recorded as patients with diabetes (according to adequate ICD-10 codes) in Poland in the years 2010-2014 amounted to $4.47 \%$ ( $\pm 0.09 \%)$, however, the average percentage of people who bought medicines related to diabetes or blood glucose meter test strips in the same period amounted to $5.88 \%$ ( $\pm 0.32 \%$ ). It is noticeable that these percentages differ by $1.41 \%$. This difference might result from the reporting system to the National Health Fund. The data transmitted by the healthcare providers to the National Health Fund concerning the granted health services include the code of its main cause (according to ICD-10) and codes of not more than three coexisting causes, essential for granting this service. Patients with diabetes usually have a few chronic diseases and diabetes may not have constituted the main cause of the granted service. The ICD-10 codes related to diabetes may thus not have been disclosed to the National Health Fund, but in spite of that prescriptions were given to the patients for reimbursable hypoglycemic agents or test strips.

The consecutive potential cause of the aforementioned difference (and in particular its increase in 2013 and 2014) could be the emergence of a group of patients who are entitled to reimbursement for metformin, despite not having a diagnosed diabetes. Pursuant to the publication of the Minister of Health of $24^{\text {th }}$ April 2013 [26] the reimbursement for metformin was widened by applying a flat-rate charge. Since 2013 metformin may be prescribed at a flat-rate under the following medical conditions: type 2 diabetes, prediabetes, glucose intolerance, insulin resistance syndromes in other cases than diabetes, the polycystic ovary syndrome. However, despite the changes concerning reimbursement for metformin in 2013, the difference between the number of people who were reported to the National Health Fund as patients with diabetes and the number of patients who filled the prescriptions for the reimbursable hypoglycemic agents or test strips in the respective years has only increased slightly (vide Table 1).

Year 2011 is an exception, as the difference between these two variables is the biggest. This is perhaps the result of the announcement of the list of reimbursable medicines on $23^{\text {rd }}$ December 2011 (with effect 
from $1^{\text {st }}$ January 2012). This list does not include certain blood glucose meter test strips for marking glucose concentration, additionally the prices for the strips and the rapid-acting insulin analogs increased significantly. Suspecting a considerable increase in pharmaceutical drug expenditure, a lot of patients at the end of 2011 purchased drugs and strips in order to hoard them. Using these reserves in the following year seems to be the cause of the reduction of the patients buying strips and pharmaceuticals related to diabetes in 2012.

According to IDF data from 2014 prevalence of diabetes in Poland in the population at the age of 20-79 amounted to $7.08 \%$ [3]. The average prevalence of diabetes indicated in our research (whether assessed on the basis of provided medical services or prescriptions) is slightly lower. This difference may result from different criteria for inclusion. Prevalence of diabetes demonstrated in various studies conducted in our country ranged from $2 \%$ for type 2 diabetes in the areas outside the large cities [11] to $22 \%$ among people over 65 years of age [20]. It is, however, difficult to compare these studies because, as previously mentioned, they were conducted in different cities or regions on the groups of patients in several age categories, they referred to different types and aspects of diabetes (in some cases diabetes was not the main subject of the research) and had a different methodology. The diabetes prevalence ranging from $4.47 \%$ to $5.88 \%$ assessed by authors of presented article is comparable to outcomes obtained in other European countries. The average diabetes prevalence rate for Europe in 2014 amounted to $7.87 \%$. Diabetes prevalence similar to Poland ranging from $4.5 \%$ to $6.0 \%$ was ascertained in the following countries: Kyrgyzstan, Uzbekistan, Tajikistan, Lithuania, Luxembourg and Great Britain. The highest prevalence of the disease was observed in Turkey (14.71\%) and Portugal (13.09\%) and the lowest in Azerbaijan (2.39\%) and Armenia (2.78\%) [3].

According to the data of the National Centre for Chronic Disease Prevention and Health Promotion (CDC) 21 million people suffered from diabetes in the USA in the same year, which is $6.7 \%$ of the population, additionally diabetes remained undiagnosed among 8 million people [27]. However, the IDF data, as well as other American studies point to higher diabetes prevalence rates in this country [28].

Prevalence of diabetes in the Polish population differs among respective voivodeships. The largest percentage of people with diabetes was in Silesian Voivodeship and amounted to $5.5 \%$, the second consecutive voivodeship was Łódź Voivodeship - 5.0\% and Opole Voivodeship came in third $-4.9 \%$. The smallest percentage of people with diabetes was noted in War-
mian-Masurian Voivodeship - 3.5\% and Subcarpathian Voivodeship - 3.6\%. It is difficult to explain where these differences come from, however the disproportions in the prevalence among respective voivodeships were also observed in the WOBASZ research [21]. The highest prevalence in this research was in the Greater Poland Voivodeship (9\%), West-Pomeranian Voivodeship (8.9\%) and Opole Voivodeship (8.3\%) and the lowest for the Subcarpathian Voivodeship (5.3\%) and the Lower-Silesian Voivodeship (5.8\%).

Our research was limited due to the lack of division into age groups as well as its retrospective character. Additionally, the results presented above relate only to diabetes that had been diagnosed previously, however it should be borne in mind that diabetes among approximately $50 \%$ of patients remains undiagnosed (unknown diabetes). It is not possible to determine the scale of this problem in Poland on the basis of our research. This poses a question how many people suffer from diabetes in our country but are not treated pharmacologically or do not perform self-monitoring (do not buy blood glucose meter test strips). Further assessment is necessary in order to answer this question.

\section{Conclusions}

1. The average prevalence of diabetes in Poland in the years $2010-2014$ amounted to $4.47 \%$ (the assessment carried out on the basis of the number of people reported to the National Health Fund as diabetes patients according to the adequate ICD-10 codes) or $5.88 \%$ (assessment on the basis of the number of people who filled the prescriptions for the reimbursable hypoglycemic agents or blood glucose meter test strips).

2. Prevalence of diabetes increases in Poland in the consecutive years.

3. Prevalence of diabetes differs among respective voivodeships.

\section{Conflict of interest declaration}

The authors do not report a conflict of interest.

\section{REFERENCES}

1. Danaei G, Finucane MM, Lu Y et al. National, regional, and global trends in fasting plasma glucose and diabetes prevalence since 1980: systematic analysis of health examination surveys and epidemiological studies with 370 country-years and 2,7 million participants. Lancet 2011; 378: 31-40.

2. Lam DW, LeRoith D. The worldwide diabetes epidemic. Curr Opin Endocrinol Diabetes Obes 2012; 19: 93-96.

3. IDF diabetes atlas sixth edition 2014 update. https://www.idf.org/ /sites/default/files/Atlas-poster-2014 EN.pdf.

4. Raport. Cukrzyca, ukryta pandemia. Sytuacja w Polsce. Edycja 2014. http://www.pfed.org.pl/uploads/1/9/9/8/19983953/cukrzycaukrytapandemia2014.pdf. 
5. Tancredi M, Rosengren A, Svensson AM et al. Excess mortality among persons with type 2 diabetes. N Engl J Med 2015; 373: 1720-1732.

6. Mathers CD, Loncar D. Projections of global mortality and burden of disease from 2002 to 2030. PLoS Med 2006; 11: e442.

7. Śliwczyski A, Czeleko T, Brzozowska M et al. Analiza publicznych wydatków na lecenie cukrzycy — Polska, rok 2013. Medycyna Metaboliczna 2014; 18: 22-25.

8. Drzewoski J, Saryusz-Wolska M, Czupryniak L. Występowanie cukrzycy typu 2 i wybranych zaburzeń metabolicznych w populacji miejskiej osób dorosłych powyżej 35 roku życia. Pol Arch Med Wewn 2001; 3: 787-791.

9. Łopatyński J, Mordarowicz G, Nicer T et al. Badania nad występowaniem cukrzycy typu 2 w populacji powyżej 35 roku życia na wsi iw mieście w regionie lubelskim. Pol Arch Med Wewn 2001; 3: 781-786.

10. Szybiński Z. Polish Multicentre Study on Diabetes Epidemiology (PMSDE) 1998-2002. Pol Arch Med Wew 2001; 16: 751-765.

11. Nowakowski A. Epidemiologia cukrzycy. Diabetologia Praktyczna 2002; 3: 181-185.

12. Wierucki $Ł$, Zdrojewski T, Mogilnaya I et al. Polski Projekt 400 Miast wyniki badań pilotażowych. Nadciśnienie Tętnicze 2004; 8: 307-317.

13. Fabian W, Majkowska L, Stefański A, Molęda P. Prevalence of diabetes, antidiabetic treatment and chronic diabetic complications reported by general practitioners. Przegl Lek 2005; 62: 201-205.

14. Sieradzki J, Wilkins A, Szczepański M. SCREEN-POL 2 - aktywne wyszukiwanie i wczesne rozpoznawanie cukrzycy typu 2 u pacjentów zgłaszających się do lekarzy podstawowej opieki zdrowotnej w Polsce. Wyniki ogólnopolskiego, wieloośrodkowego programu przesiewowego. Diab Prakt 2005; 6: 103-114.

15. Szurkowska M, Szafraniec K, Gilis-Januszewska A et al. Incidence of carbohydrate tolerance disorders among adult residents of Krakow - a screening study. Przegl Lek 2006; 63: 728-732.

16. Zatońska K, llow R, Regulska-llow B et al. Prevalence of diabetes mellitus and IFG in the prospective cohort 'PONS' study - baseline assessment. Ann Agric Environ Med 2011; 18: 265-269.

17. Śliwczyński A, Brzozowska M, Czeleko T et al. Comparison of indicators of the use of insulin and oral diabetes medication in a Polish population of patients in urban and rural areas in the years 2008, 2011 and 2012. Ann Agric Environ Med 2104; 21: 302-313.
18. Zdrojewski T, Bandosz P, Szpakowski P et al. Rozpowszechnienie głównych czynników ryzyka chorób układu sercowo-naczyniowego w Polsce. Wyniki badania NATPOL PLUS. Kardiol Pol 2004; 61 (suppl 4): 5-26.

19. Rutkowski M, Bandosz P, Czupryniak L et al. Prevelence of diabetes and impaired fasting glucose in Poland - the NATPOL 2011 Study. Diabet Med 2014; 31: 1568-1571.

20. Januszkiewicz-Caulier J, Mossakowska M, Zdrojeski T et al. Cukrzyca i jej powikłania w podeszłym wieku. In: Mossakowska M, Więcek A, Błędowski P (ed.). Aspekty medyczne, psychologiczne, socjologiczne i ekonomiczne starzenia się ludzi w Polsce. Termedia Wydawnictwo Medyczne, Poznań 2012: 169-179.

21. Polakowska M, Piotrowski W. Incidence of diabetes in the Polish population. Results of the Multicenter Polish Population Health Status Study - WOBASZ. Pol Arch Med Wewn 2011; 121: 156-163.

22. Ustawa z dnia 27 sierpnia 2004 r. o świadczeniach opieki zdrowotnej finansowanych ze środków publicznych. Dz.U. 2008 nr 164 poz. 1027

23. Rozporządzenie Ministra Zdrowia z dnia 20 czerwca 2008 r. w sprawie zakresu niezbędnych informacji gromadzonych przez świadczeniodawców, szczegółowego sposobu rejestrowania tych informacji oraz ich przekazywania podmiotom zobowiązanym do finansowania świadczeń ze środków publicznych. Dz.U. 08.123.801 z późn. zm.

24. Rozporządzenie Ministra Zdrowia z dnia 23 grudnia 2011 r. w sprawie informacji gromadzonych przez apteki oraz informacji przekazywanych Narodowemu Funduszowi Zdrowia. Dz.U. 2011.294.1742

25. http://demografia.stat.gov.pl/bazademografia/.

26. Dziennik Urzędowy Ministra Zdrowia 2013.17.

27. Centers for Disease Control and Prevention. National Diabetes Statistics Report: Estimates of Diabetes and Its Burden in the United States, 2014. US Department of Health and Human Services, Atlanta, GA, 2014.

28. Menke A, Casagrande S, Geiss L, Cowie CC. Prevalence of and Trends in Diabetes Among Adults in the United States, 1988-2012. JAMA 2015; 314: 1021-1029. 